\title{
A prospective observational study on acute exacerbation of chronic obstructive pulmonary disease in pulmonology department of tertiary care hospital
}

Sreenu Thalla ${ }^{1 *}$, Akhila Yerubandi², Sk. Hafeezunnisa ${ }^{2}$, Sk. Jareena ${ }^{2}$ and Sivakshari Makkapati

\begin{abstract}
Background: Chronic obstructive pulmonary disease (COPD) is a common, preventable, and treatable disease that is characterized by persistent respiratory symptoms and airflow limitation that is due to airway and/or alveolar abnormalities usually caused by significant exposure to noxious particles or gasses. An acute exacerbation of COPD refers to a flare up or episode where a person breathing becomes worse than normal. An acute exacerbation of COPD refers to a flare up or episode where a person breathing becomes worse than normal. Acute exacerbation in COPD (AECOPD) is frequent in the course of the illness and is the most common reason for medical visits, hospital admissions, and mortality among these patients. Exacerbations of COPD are associated with increased morbidity and mortality. To assess the exposure and severity of acute exacerbations of COPD with COPD Assessment Test (CAT Scale) and mMRC (modified Medical Research Council) Dyspnea scale. Study design was a hospital-based prospective observational study. Study site was conducted at Pulmonology Department of Government General Hospital, Vijayawada.

Results: The total patients were 197. Out of which, 119 were from In-patient Department (IPD) and 78 were from Out-patient Department (OPD). In this study, males were 167 (85\%), among which, IPD were 97 (49\%), OPD were 70 (36\%), and females were 30 (15\%), among which, IPD were 22 (11\%), OPD were 8 (4\%).

Conclusion: The morbidity and mortality of COPD have been increased in recent years. This study concludes that there is a relation between risk of acute exacerbations in COPD with habitual history and occupational history. Increase in exposure to occupational hazards, smoking habit leads to an increase in risk of acute exacerbations in COPD patients. The level of severity was more in smokers and the patients who had biomass, organic dust, and mineral exposure. When severity was observed, group D severity is more observed in population according to CAT scale and mMRC dyspnea scale.
\end{abstract}

Keywords: Pulmonology, Out-patients, In-patients, Department, Acute exacerbations, Chronic, COPD, Fever, Chest tightness, Shortness of breath, CAT, MMRC

\footnotetext{
* Correspondence: sreenuthalla87@gmail.com

1 Department of Pharmacology, SRM College of Pharmacy, SRMIST,

Kattankulathur, Kancheepuram, Tamil Nadu 603203, India

Full list of author information is available at the end of the article
}

\section{Springer Open}

(c) The Author(s). 2020 Open Access This article is licensed under a Creative Commons Attribution 4.0 International License, which permits use, sharing, adaptation, distribution and reproduction in any medium or format, as long as you give appropriate credit to the original author(s) and the source, provide a link to the Creative Commons licence, and indicate if changes were made. The images or other third party material in this article are included in the article's Creative Commons licence, unless indicated otherwise in a credit line to the material. If material is not included in the article's Creative Commons licence and your intended use is not permitted by statutory regulation or exceeds the permitted use, you will need to obtain permission directly from the copyright holder. To view a copy of this licence, visit http://creativecommons.org/licenses/by/4.0/. 


\section{Background}

Chronic obstructive pulmonary disease (COPD) is a common, preventable, and treatable disease that is characterized by persistent respiratory symptoms and airflow limitation that is due to airway and/or alveolar abnormalities usually caused by significant exposure to noxious particles or gasses. An acute exacerbation of COPD refers to a flare up or episode where a person breathing becomes worse than normal [1]. Acute exacerbation in COPD (AECOPD) is frequent in the course of the illness and is the most common reason for medical visits, hospital admissions, and mortality among these patients. Exacerbations of COPD are associated with increased morbidity and mortality [2].

The prevalence of COPD disease about 251 million cases in 2016 and the deaths estimated were 3.17 million in 2015 globally and the percentage is about 5\% deaths in a year were estimated globally [3]. The incidence rates were higher in men than in women above the age of 60 years people $[4,5]$. As of 2016, COPD is the second biggest cause of death in India [6, 7]. The prevalence ranged between 2 and $22 \%$ among the men and 1.2 to $19 \%$ among women in different population-based studies across India [8].

Cigarette smoking is the most common cause of COPD that accounts for about 85 to $90 \%$ of cases. The other causes for COPD include exposure to environmental smoke, passive smoke, occupational exposure, and genetic predisposition [9-11]. The common symptoms of COPD are shortness of breath, cough (with or without expectoration), fever, chest tightness, and hemoptysis [12-14].

The main goals involved in the treatment of COPD are to provide symptomatic relief and reduce the risk of future prevention of exacerbation, reduce disease progression, and reduce mortality [2]. The primary goals of pharmacotherapy are to decrease the severity of symptoms, improve the overall health status and reduce the disease frequency, complications, and severity of the exacerbations $[15,16]$. Based on Global Initiative for Chronic Obstructive Pulmonary Disease (GOLD) Guidelines (2019), drug classes like short-acting beta 2 agonists (SABA), long-acting beta 2 agonists (LABA), short-acting anti-cholinergic/ muscarinic agonists (SAMA), long-acting anticholinergic/muscarinic agonists (LAMA), inhaled or

Table 1 Distribution based on gender

\begin{tabular}{llll}
\hline Gender & IPD (\%) & OPD (\%) & No. of patients (\%) \\
\hline Male & $97(49)$ & $70(36)$ & $167(85)$ \\
Female & $22(11)$ & $8(4)$ & $30(15)$ \\
Total & 119 & 78 & 197 \\
\hline
\end{tabular}

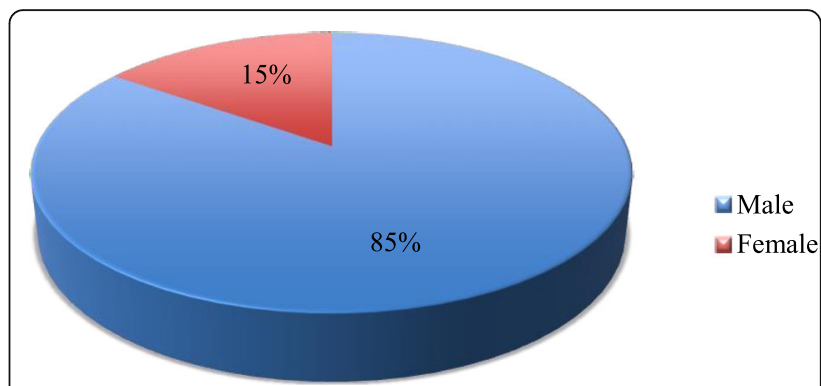

Fig. 1 Distribution based on gender

systemic corticosteroids. Hospitalized patients with COPD should be provided with antibiotic therapy, appropriate supportive care, and monitoring of oxygen status [17-20]. Therapeutic options for acute exacerbations of COPD include oxygen therapy, antibiotics, corticosteroids, bronchodilators, noninvasive mechanical ventilation [21-23]. The main objectives of the study are to collect and document the patient data and previous medication use, to assess the etiology for exacerbations and stages of COPD with CAT (COPD Assessment Test) and MMRC (Modified Medical Research Council) dyspnea scale, to assess the drug therapy and to identify any drug for inappropriate use, undertaking clinical interventions, documenting suspected drug reactions for future references, follow-up to assess the outcomes of the drug therapy and management, to assess adherence toward therapy every week for a period of 6 months [24-27].

The current knowledge on various aspects of COPD is to be studied further. Further studies should be done on the impact of risk factors and triggers such as smoking, severe airflow limitations, bacterial and

Table 2 Clinical profile of the patients

\begin{tabular}{ll}
\hline Parameter & $N(\%)$ \\
\hline Age in years, mean & $58.24 \pm 5.79$ years \\
Male & $167(85)$ \\
Female & $30(15)$ \\
Age at onset of symptoms, mean & 56.3 \\
Years of disease, mean & 3.5 \\
Patients associated with diseases & $94(47.7)$ \\
Hypertension & $46(23.3)$ \\
Diabetes mellitus & $26(13.2)$ \\
Pulmonary tuberculosis & $22(11.2)$ \\
Patients with concomitant treatments & $78(39.6)$ \\
Anti-hypertensive drugs & $38(19.3)$ \\
Hypoglycemic agents & $24(12.2)$ \\
Anti-tubercular drugs & $16(8.1)$ \\
\hline
\end{tabular}


Table 3 Distribution of number of exacerbations

\begin{tabular}{lll}
\hline Gender & \multicolumn{2}{l}{ No. of exacerbations } \\
\cline { 2 - 3 } & $\leq \mathbf{1}$ & $\geq \mathbf{2}$ \\
\hline Male & $62(31.5)$ & $105(53.3)$ \\
Female & $10(5.1)$ & $20(10.1)$ \\
\hline
\end{tabular}

viral infections, bronchiectasis, and comorbidities. Severe exacerbations indicate the worsening of survival outcome [28]. The present study is to assess the prescribing patterns and evaluate the clinical interventions associated with exacerbations in COPD. Previous medication use and suspected adverse drug reactions in the drug therapy for COPD is documented. This study also identify the etiology for exacerbations based on various criteria and stages of COPD with COPD Assessment Test (CAT), Modified Medical Research Council (MMRC) dyspnea scale, and drug therapy to identify any drug for inappropriate use, medication adherence and to provide patient education to reduce the exacerbations in COPD [29].

\section{Methods}

\section{Source of data}

Data was collected from prescriptions of the patients in the Pulmonology Department of IP and OP of the hospital.

Evaluation of patient medication charts in follow-up cases.

\section{Study site}

This study was conducted at the Pulmonology Department of Government General Hospital, Vijayawada. Study design-a hospital-based prospective observational study.

\section{Sample size}

A total of 197 patients who fulfilled the inclusion and exclusion criteria were selected for the study. Out of which 119 patients are from the in-patient department (IPD) and 78 patients are from out-patient department (OPD).

\section{Study duration}

The study is conducted over a period of 6 months from August 2019 to January 2020.

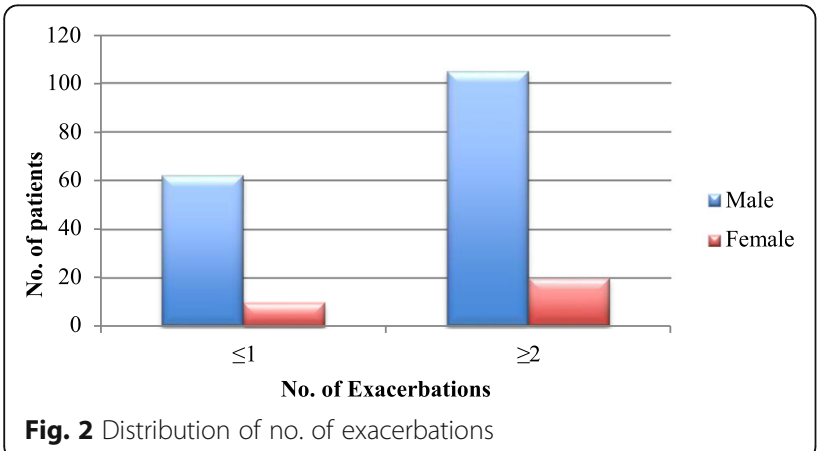

Table 4 Distribution of age with gender

\begin{tabular}{llll}
\hline $\begin{array}{l}\text { Age } \\
\text { (years) }\end{array}$ & Gender & Total \\
\cline { 2 - 3 } & Male (\%) & Female (\%) & (\%) \\
\hline$<20$ & $1(0.5)$ & $1(0.5)$ & $2(1.0)$ \\
$21-40$ & $6(3.0)$ & $2(1.0)$ & $8(4.1)$ \\
$41-60$ & $78(39.6)$ & $16(8.1)$ & $94(47.7)$ \\
$61-80$ & $81(41.1)$ & $11(5.6)$ & $92(46.7)$ \\
$>80$ & $1(0.5)$ & $0(0)$ & $1(0.5)$ \\
\hline
\end{tabular}

\section{Study criteria}

The study is carried out considering the following criteria.

\section{Inclusion criteria}

Patients who are suffering with COPD.

\section{Exclusion criteria}

Patients with no COPD.

Patients from other departments.

\section{Data analysis}

All the collected data were analyzed to assess the etiology and severity of acute exacerbations of COPD occurred in the tertiary care hospital. The predisposing factors like age and gender were determined through the analysis. Most common reasons for developing acute exacerbations were determined.

All patients were monitored from the day of admission to the day of discharge. The patient data was collected and documented in the prepared IP and OP data collection forms.

\section{Statistical analysis}

Standard statistics were used to describe patient demographics. Mean and standard deviation were calculated for age, onset of symptoms, past years of disease. The statistical significance was tested using chi-square test manually and two-way ANOVA test using the Microsoft Excel 2011.

\section{Results}

The present prospective observational study was done at the General Medicine Department, Government General Hospital, Vijayawada, over a period of 6 months since July 2019 to December 2019. A total number of 197 cases were collected from the Pulmonology Department of Government General Hospital, Vijayawada.

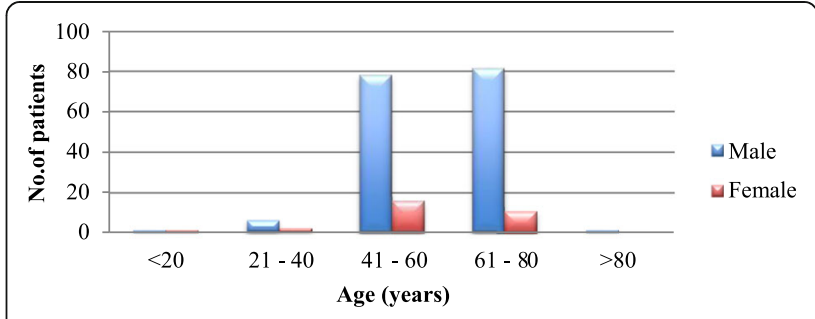

Fig. 3 Distribution of age with gender 
Table 5 Distribution based on symptoms

\begin{tabular}{ll}
\hline Complaints & No. of patients \\
\hline Shortness of breath & 187 \\
Cough & 161 \\
Fever & 60 \\
Chest tightness & 67 \\
Hemoptysis & 6 \\
\hline
\end{tabular}

\section{Distribution of gender}

Clinical profile

Distribution of number of exacerbations

Distribution of age with gender

\section{Distribution of symptoms}

\section{Distribution of dyspnea grades}

Distribution of habitual exposure with exacerbations

Distribution of occupational exposure with exacerbations

Distribution of habitual exposure with gender

Distribution of occupational exposure with gender

Distribution of habitual exposure with severity

Statistical significance of habitual exposure \& severity by 2way ANOVA

Distribution of occupational exposure with severity Statistical significance of occupational exposure, severity by 2-way ANOVA

\section{Discussion}

Gender distribution has been presented in Table 1 and Fig. 1. The total patients were 197. Out of which 119 were from In-patient Department (IPD) and 78 were

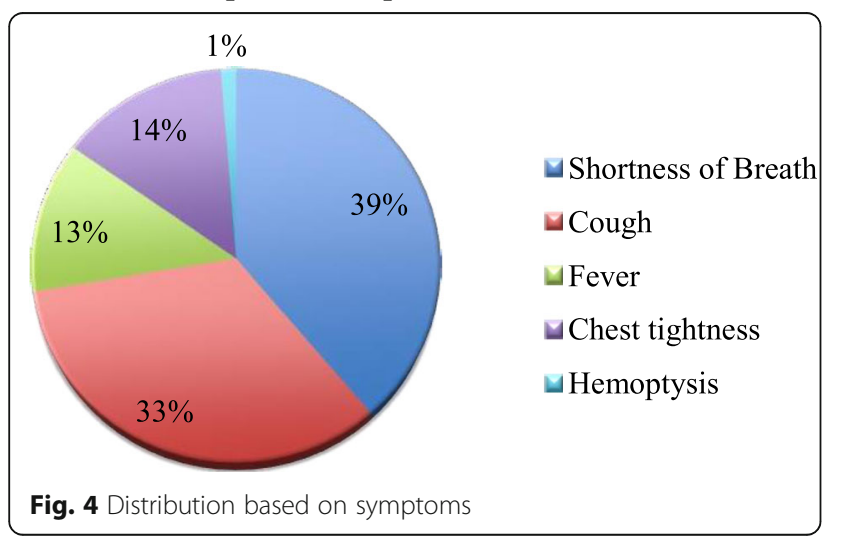

Table 6 Distribution based on dyspnea grades

\begin{tabular}{ll}
\hline Dyspnea grades & No. of patients (\%) \\
\hline Grade I & $9(4.8)$ \\
Grade II & $37(19.8)$ \\
Grade III & $54(28.9)$ \\
Grade IV & $87(46.5)$ \\
\hline
\end{tabular}

from Out-patient Department (OPD). In this study, males were 167 (85\%), among which, IPD were 97 (49\%), OPD were 70 (36\%), and females were $30(15 \%)$, among which, IPD were $22(11 \%)$, OPD were $8(4 \%)$. Clinical profile of the patients has been presented in Table 2 . The parameters included are mean age of 58.24 \pm 5.79 years, mean age at onset of symptoms is 56.3 years, mean years of disease in past is 3.5 years. No. of exacerbation distributed among the gender has been presented in Table 3 and Fig. 2. Number of exacerbations was categorized as $\leq 1$ and $\geq 2$. Males and female with $\leq 1$ exacerbation were $62(31.5 \%)$ and $10(5.1 \%)$ respectively. Males and females with $\geq 2$ exacerbations were 105 (53.3\%) and $20(10.1 \%)$ respectively. Distribution of age with gender has been presented in Table 4 and Fig. 3. Age with gender was distributed and more number of patients were observed in 41-60 years of about 94 patients followed by 61-80 years of about 92 patients, 2140 years of about 8 patients, < 20 years of about 2 patients and $>80$ years of about 1 patient. Complaints based distribution has been presented in Table 5 and Fig. 4. Based on complaints more number of patients were observed in shortness of breath of about 182 patients followed by cough of about 161 patients, chest pain of about 67 patients, fever of about 60 patients, and least was observed in hemoptysis of about 6 patients. Dyspnea grade distribution has been presented in Table 6 and Fig. 5 . More number of patients were observed in grade IV of

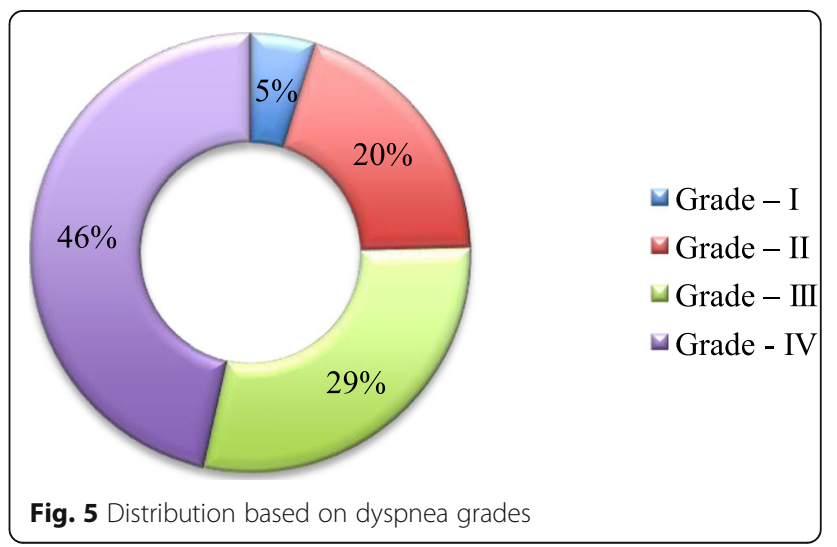


Table 7 Distribution of habitual exposure with number of exacerbations

\begin{tabular}{llll}
\hline $\begin{array}{l}\text { Habitual } \\
\text { exposure }\end{array}$ & $\begin{array}{l}\leq \mathbf{1} \text { exacerbations } \\
\mathbf{( \% )}\end{array}$ & $\begin{array}{l}\geq \mathbf{2} \text { exacerbations } \\
\mathbf{( \% )}\end{array}$ & $\begin{array}{l}\text { Total } \\
\mathbf{( \% )}\end{array}$ \\
\hline Smokers & $30(15.2)$ & $59(29.9)$ & 89 \\
& & $5(2.5)$ & $13(6.6)$ \\
$\begin{array}{l}\text { Ex-smokers }<6 \\
\text { months }\end{array}$ & $8(4.1)$ & & \\
$\begin{array}{l}\text { Ex-smokers }>6 \\
\text { months }\end{array}$ & $21(10.6)$ & $46(23.3)$ & $\begin{array}{l}67 \\
(34.0)\end{array}$ \\
Non-smokers & $13(6.6)$ & $15(7.6)$ & 28 \\
& & & $(14.2)$ \\
\hline
\end{tabular}

about 87 patients followed by grade III of about 54 patients, grade II of about 37 patients, and least was observed in grade I of about 9 patients. Habitual exposure with number of exacerbations distribution has been presented in Table 7 and Fig. 6. More number of exacerbations was observed in smokers of about 89 patients followed by ex-smokers more than 6 months of about 67 patients, nonsmokers of about 13 patients, and least was observed in ex-smokers less than 6 months of about 13 patients.

Habitual exposure with a number of exacerbations distribution has been presented in Table 7 from this table, we observed the association between the habitual exposures with the number of exacerbations by using the chi-square test. The calculated value is 5.104 and the table value is 3.84 . This proves that the habitual exposure influences the number of exacerbations. Occupational exposure with the number of exacerbations has been presented in Table 8 and Fig. 7. More number of patients was observed in mineral dust of about 88 patients followed by biomass exposure of about 46 patients, organic dust of about 43 patients, and least was observed in no exposure of about 20 patients. Statistical analysis of occupational exposure by chi-square test: Occupational exposure with number of exacerbations has
Table 8 Distribution of occupational exposure with number of exacerbations

\begin{tabular}{llll}
\hline $\begin{array}{l}\text { Occupational } \\
\text { exposure }\end{array}$ & $\begin{array}{l}\leq \mathbf{1} \text { exacerbations } \\
\mathbf{( \% )}\end{array}$ & $\begin{array}{l}\mathbf{2} \text { exacerbations } \\
\mathbf{( \% )}\end{array}$ & $\begin{array}{l}\text { Total } \\
\mathbf{( \% )}\end{array}$ \\
\hline Biomass exposure & $23(11.7)$ & $23(11.7)$ & $\begin{array}{l}46 \\
(23.3)\end{array}$ \\
Mineral dust & $25(12.7)$ & $63(32.0)$ & $\begin{array}{l}88 \\
(44.7)\end{array}$ \\
Organic dust & $16(8.1)$ & $27(13.7)$ & 43 \\
& & & $(21.8)$ \\
No exposure & $5(2.5)$ & $15(7.6)$ & 20 \\
& & & $(10.1)$ \\
\hline
\end{tabular}

been presented in Table 8; from this table, we observed the association between habitual exposure and occupational exposure with number of exacerbations by using the chi-square test. The calculated value is 7.48 and the table value is 3.84 . This proves that the occupational exposure influences the number of exacerbations. Gender distribution based on habitual exposure has been presented in Table 9 and Fig. 8. About 94 patients were smokers followed by ex-smokers more than 6 months in 65 patients, non-smokers were 26 patients, and least was observed in ex-smokers less than 6 months in 12 patients. Gender-based distribution of occupational exposure has been presented in Table 10 and Fig. 9. About $88 \%$ of patients were exposed to mineral dust followed by $46 \%$ exposed to biomass, $43 \%$ exposed to organic dust and only $20 \%$ were not exposed to any type of pollution. Habitual exposure with severity has been presented in Table 11 and Fig. 10. Habitual exposure with respect to severity was distributed. More number of patients was observed in group D of about 73 patients followed by group B of about 60 patients, group A of about 37 patients, and least was observed in group $\mathrm{C}$ of about 27 patients. Habitual exposure with severity has

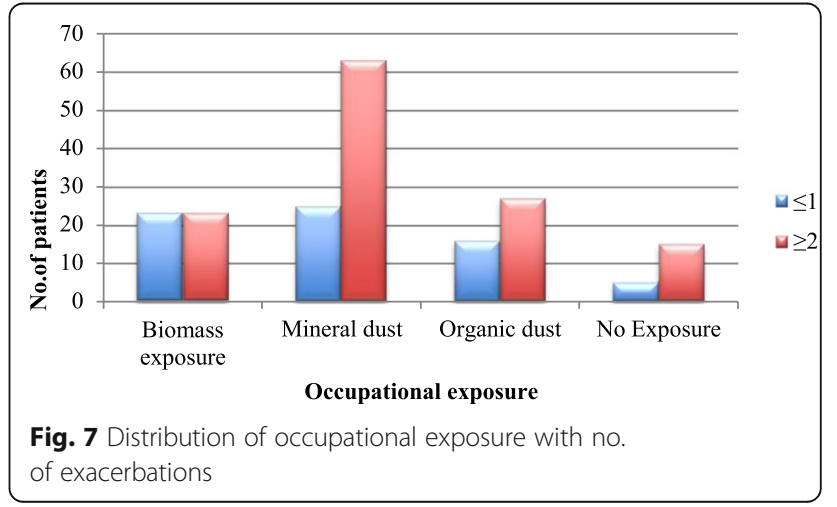

Fig. 6 Distribution of habitual exposure with no. of exacerbations

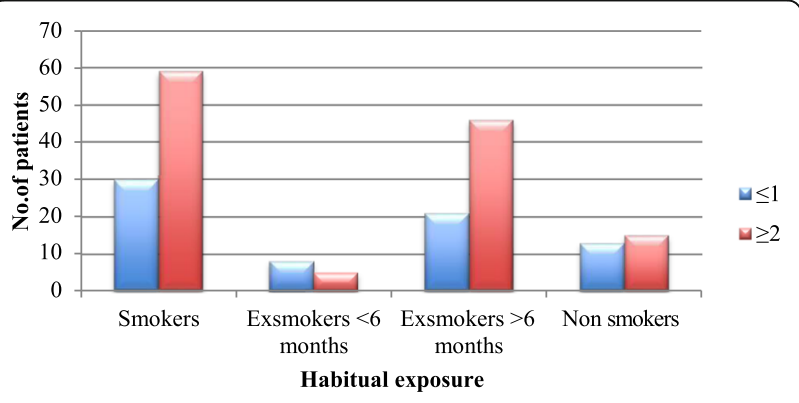


Table 9 Distribution of habitual exposure with respect to gender

\begin{tabular}{llll}
\hline Habitual exposure & Male (\%) & Female (\%) & Total (\%) \\
\hline Smokers & $89(45.2)$ & $5(2.5)$ & $94(47.7)$ \\
Ex-smokers < 6 months & $12(6.1)$ & $0(0)$ & $12(6.1)$ \\
Ex-smokers $>$ 6 months & $61(31.0)$ & $4(2.0)$ & $65(33.0)$ \\
Non-smokers & $18(9.1)$ & $8(4.1)$ & $26(13.2)$ \\
\hline
\end{tabular}

been presented in Tables 11 and 12 from this, we observed that the impact of habitual exposure on severity grouping of the disease to analyze that by the ANOVA 2-way classification. The row characteristic was habitual exposure (smokers, ex-smokers $<6$ months, ex-smokers > 6 months, and nonsmokers), and the column characteristic was severity grouping of the disease (group A, group B, group C,

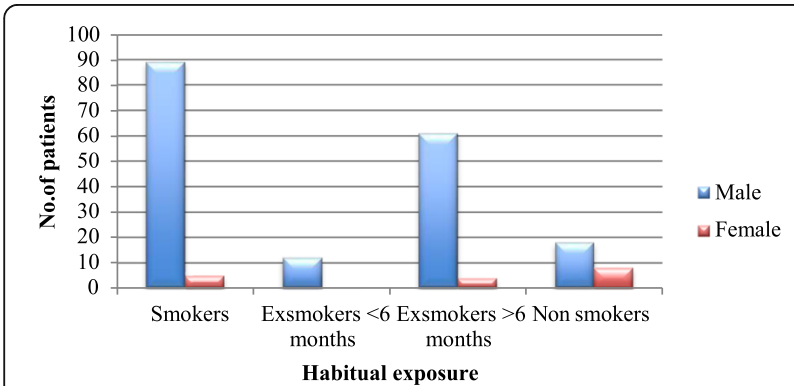

Fig. 8 Distribution of habitual exposure with gender

and group D). We obtained the results using Excel 2011. As per habitual exposure concerned, which shows there is a significant difference in habitual exposure. There is a significant difference in the severity grouping of the disease. Occupational exposure based on severity grouping has been presented in Table 13 and Fig. 11, occupational exposure with respect to severity grouping was distributed. More number of patients were observed in group D of about 74 patients followed by group B of about 60

Table 10 Distribution of occupational exposure with respect to gender

\begin{tabular}{llll}
\hline Occupational exposure & Male (\%) & Female (\%) & Total (\%) \\
\hline Biomass exposure & $36(18.3)$ & $10(5.1)$ & $46(23.3)$ \\
Mineral dust & $78(39.6)$ & $10(5.1)$ & $88(44.7)$ \\
Organic dust & $41(20.8)$ & $2(1.0)$ & $43(21.8)$ \\
No Exposure & $12(6.1)$ & $8(4.1)$ & $20(10.1)$ \\
\hline
\end{tabular}

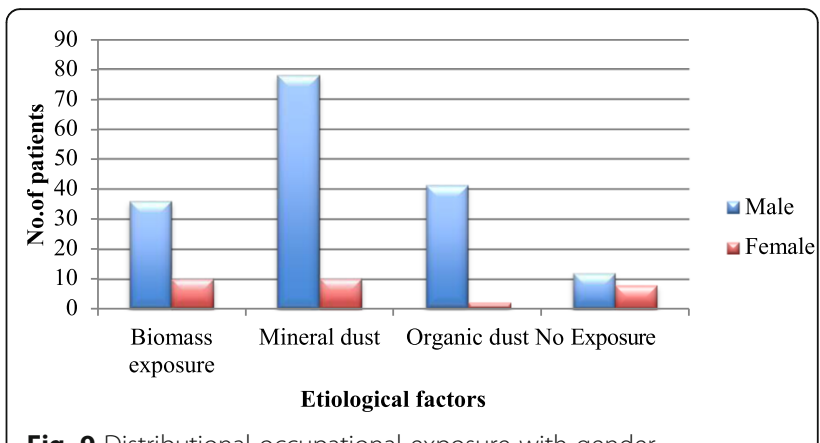

Fig. 9 Distributional occupational exposure with gender

patients, group A of about 36 patients, and least was observed in group $\mathrm{C}$ of about 27 patients. Statistical significance of occupational exposure has been presented in Tables 13 and 14, we observed that the impact of occupational exposure on severity

Table 11 Distribution of habitual exposure with severity grouping

\begin{tabular}{lllll}
\hline Habitual & \multicolumn{4}{l}{ Severity grouping } \\
\cline { 2 - 5 } Exposure & $\begin{array}{l}\text { Group A } \\
\text { (\%) }\end{array}$ & $\begin{array}{l}\text { Group B } \\
\text { (\%) }\end{array}$ & $\begin{array}{l}\text { Group C } \\
\text { (\%) }\end{array}$ & $\begin{array}{l}\text { Group D } \\
\text { (\%) }\end{array}$ \\
\hline $\begin{array}{l}\text { Smokers } \\
\begin{array}{l}\text { Ex-smokers < } 6 \\
\text { months }\end{array}\end{array}$ & $3(1.5)$ & $6(3.0)$ & $1(0.5)$ & $3(1.5)$ \\
$\begin{array}{l}\text { Ex-smokers }>6 \\
\text { months }\end{array}$ & $11(5.6)$ & $18(9.1)$ & $9(4.6)$ & $27(13.7)$ \\
Non-smokers & $5(2.5)$ & $8(4.1)$ & $6(3.0)$ & $7(3.5)$ \\
Total & $37(18.8)$ & $60(30.5)$ & $27(13.7)$ & $73(37.0)$ \\
\hline
\end{tabular}

grouping of the disease to analyze that by the ANOVA 2-way classification. The row characteristic was occupational exposure (biomass exposure, mineral dust exposure, organic dust exposure, and no exposure) and the column characteristic was severity grouping of the disease (group A, group B, group C,

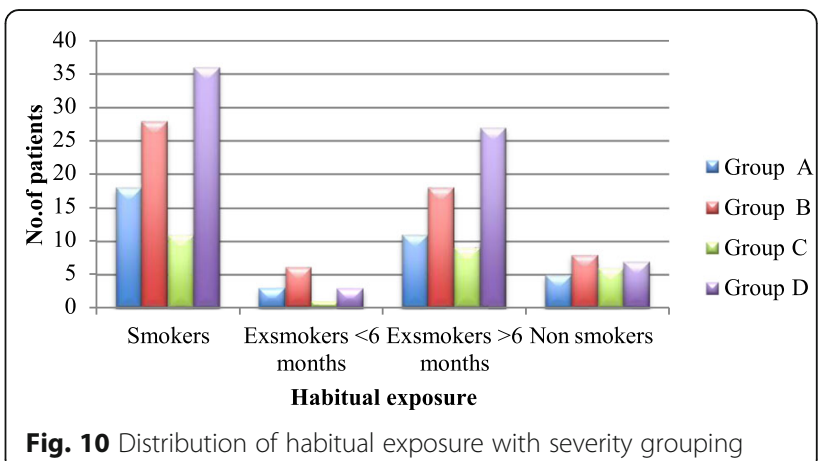


Table 12 ANOVA Two-way classification

\begin{tabular}{lllllll}
\hline $\begin{array}{l}\text { Source of } \\
\text { variation }\end{array}$ & $\begin{array}{l}\text { Sum of } \\
\text { squares }\end{array}$ & $\begin{array}{l}\text { Degrees } \\
\text { of } \\
\text { freedom }\end{array}$ & $\begin{array}{l}\text { Mean sum } \\
\text { of squares }\end{array}$ & $\begin{array}{l}F \\
\text { test }\end{array}$ & $\begin{array}{l}\boldsymbol{P} \text { value } \\
\text { critical } \\
\text { value }\end{array}$ \\
\hline $\begin{array}{l}\text { Habitual } \\
\text { exposure }\end{array}$ & 1004.19 & 3 & 334.73 & 12.14 & 0.001 & 3.86 \\
$\begin{array}{l}\text { Severity } \\
\text { grouping }\end{array}$ & 331.19 & 3 & 110.40 & 4.00 & 0.046 & 3.86 \\
Error & 248.06 & 9 & 27.56 & & & \\
Total & 1583.44 & 15 & & & & \\
\hline
\end{tabular}

and group D). We obtained the results using Excel 2011. As per occupational exposure concerned, which shows there is a significant difference in occupational exposure. There is no significance in severity grouping of the disease.

Table 13 Distribution of occupational exposure with severity grouping

\begin{tabular}{lllll}
\hline $\begin{array}{l}\text { Occupational } \\
\text { exposure }\end{array}$ & \multicolumn{4}{l}{ Severity grouping } \\
\cline { 2 - 5 } & $\begin{array}{l}\text { Group A } \\
\text { (\%) }\end{array}$ & $\begin{array}{l}\text { Group B } \\
\mathbf{( \% )}\end{array}$ & $\begin{array}{l}\text { Group C } \\
\text { (\%) }\end{array}$ & $\begin{array}{l}\text { Group D } \\
\text { (\%) }\end{array}$ \\
\hline $\begin{array}{l}\text { Biomass } \\
\text { exposure }\end{array}$ & $14(7.1)$ & $12(6.1)$ & $5(2.5)$ & $15(7.6)$ \\
Mineral dust & $14(7.1)$ & $31(15.7)$ & $9(4.6)$ & $34(17.3)$ \\
Organic dust & $4(2.0)$ & $15(7.6)$ & $9(4.6)$ & $15(7.6)$ \\
No exposure & $4(2.0)$ & $2(1.0)$ & $4(2.0)$ & $10(5.1)$ \\
Total & $36(18.3)$ & $60(30.5)$ & $27(13.7)$ & $74(37.6)$ \\
\hline
\end{tabular}

\section{Conclusion}

The morbidity and mortality of COPD have been increased in recent years. This study concludes that there is a relation between risk of acute exacerbations in COPD with habitual history and occupational history. Increase in exposure to occupational hazards, smoking habit leads to an increase in risk

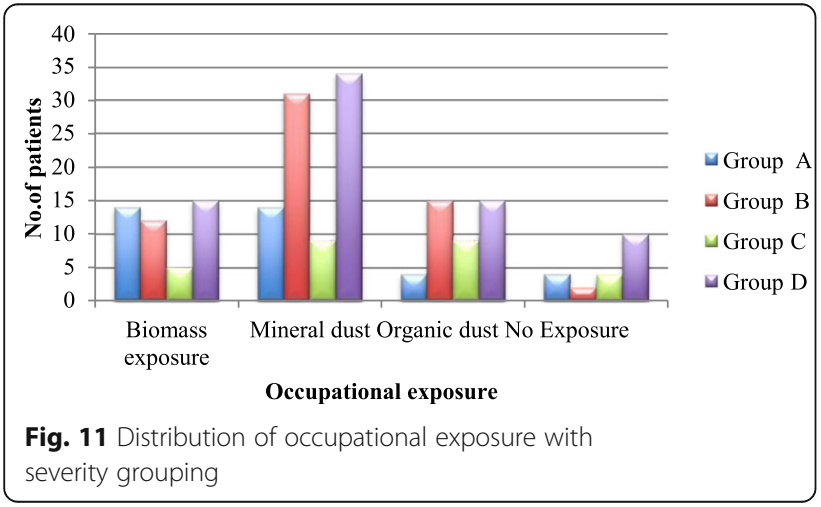

Table 14 ANOVA two-way classification of occupational exposure

\begin{tabular}{lllllll}
\hline $\begin{array}{l}\text { Source of } \\
\text { variation }\end{array}$ & $\begin{array}{l}\text { Sum of } \\
\text { squares }\end{array}$ & $\begin{array}{l}\text { Degrees } \\
\text { of } \\
\text { freedom }\end{array}$ & $\begin{array}{l}\text { Mean sum } \\
\text { of squares }\end{array}$ & $\begin{array}{l}\boldsymbol{F} \\
\text { test }\end{array}$ & $\begin{array}{l}\boldsymbol{P} \text { value } \\
\text { critical } \\
\text { value }\end{array}$ \\
\hline $\begin{array}{l}\text { Occupational } \\
\text { exposure }\end{array}$ & 601.69 & 3 & 200.56 & 6.22 & 0.014 & 3.86 \\
$\begin{array}{l}\text { Severity } \\
\text { grouping }\end{array}$ & 349.69 & 3 & 116.56 & 3.62 & 0.06 & 3.86 \\
Error & 290.06 & 9 & 32.23 & & & \\
Total & 1241.44 & 15 & & & & \\
\hline
\end{tabular}

of acute exacerbations in COPD patients. The level of severity was more in smokers and the patients who had biomass, organic dust, and mineral exposure. When severity was observed, group D severity is more observed in population according to CAT scale and mMRC dyspnea scale. Males have the highest prevalence than females due to various etiological factors such as habitual history or occupational history, comorbidities, and lifestyle.

\section{Abbreviations}

AECOPD: Acute exacerbation in chronic obstructive pulmonary disease; COPD: Chronic obstructive pulmonary disease; ANOVA: Analysis of variance: IPD: In-patient department; OPD: Out-patient department; CAT: COPD assessment test; MMRC: Modified Medical Research Council; GOLD: Global Initiative for Chronic Obstructive Pulmonary Disease; SABA: Short-acting beta 2 agonists; LABA: Long-acting beta 2 agonists; SAMA: Short-acting muscaranic agonists; LAMA: Long-acting muscaranic agonists

\section{Acknowledgements}

We gratefully acknowledge the Doctors of Pulmonology Department of Government General Hospital (GGH), Vijayawada, and Dr. K. Padmalatha, Principal of Vijaya Institute of Pharmaceutical Sciences for Women for support.

\section{Authors' contributions}

ST contributed to the idea of the study and work proposal and supervision; $\mathrm{SH}$ and SJ collected the patient data, consent for the study, and documentation regarding COPD with acute exacerbations; and AY and SM were the contributors for analyzing, interpreting, and writing the manuscript. "All authors read and approved the manuscript."

\section{Funding}

Nil

Availability of data and materials

All data generated or analyzed during this study are included in this published article.

\section{Ethics approval and consent to participate}

Written informed consent was signed by all study participants. The study approval was taken from the Institutional Ethical Committee (IEC), Siddhartha Medical College and Government General Hospital, Vijayawada, held on 18 August 2019, with Ethical Committee number-IEC/2019/096E/SMC.

\section{Consent for publication}

Not applicable

\section{Competing interests}

The authors declare that they have no competing interests.

\section{Author details}

${ }^{1}$ Department of Pharmacology, SRM College of Pharmacy, SRMIST, Kattankulathur, Kancheepuram, Tamil Nadu 603203, India. '2Department of 
Pharmacy Practice, Vijaya Institute of Pharmaceutical Sciences for Women, Enikepadu, Vijayawada, Andhra Pradesh 521108, India.

\section{Received: 29 September 2020 Accepted: 20 November 2020}

Published online: 02 December 2020

\section{References}

1. Global Initiative for Chronic Obstructive Pulmonary Disease, Global Strategy for the Diagnosis, Management and Prevention of Chronic Obstructive Pulmonary Disease. NHLBI/WHO workshop report. Bethesda, MD: National Heart, Lung and Blood Institute, April 2001; Report of 2019.

2. Jameson, Fauci, Kasper, Hauser, Longo, Loscalzo, Harrisons Principles of Internal Medicine, 20th edition, Mc Graw Hill Education, 1990-1998.

3. Raherison C, Girodet P-O et al (2009) Eur RespirJ 18:213-221

4. Doucet M, Rochette L, Hamel D (2016) Incidence, prevalence and mortality trends in chronic obstructive pulmonary disease over 2001 to 2011: a public health point of view of the burden. Can Respir:01-10

5. Sogaard M, Madsen M, Lokke A, Hilberg O, Sorensen HT, Thomsen RW (2016) Incidence and outcomes of patients hospitalized with COPD exacerbation with and without pneumonia. Int J Chron Obst Pulmon Dis 11:455-465

6. MacNee W (2006) ABC of chronic obstructive pulmonary disease, pathology, pathogenesis and pathophysiology. Br Med J 332:1202-1204

7. Ladhani S (2016) COPD - an Indian perspective. J Lung Pulmon Respir Res 3(1):24-25. https://doi.org/10.15406/jlprr.2016.03.00070

8. Joseph T. DiPiro, Robert L. Talbert, Gary C. Yee, Gary R. Matzke, Barbara G. Wells, L. Michael Posey, Pharmacotherapy a pathophysiologic approach, 10th edition, Mc Graw Hill Education, 543-554.

9. A Bourdin, P R. Burgel, P. Chanez, G. Garcia, T. Perez, N. Roche. Recent advances in COPD: pathophysiology, respiratory physiology and clinical aspects, including comorbidities. Eur. Respir. J. 2009. 18114 196-212.

10. Calderazzo MA, Trujillo Toralbo MB, Finney $\amalg$, Singanayagam A, Bakhsoliani $E$ Padmanaban V, Kebadze T, Aniscenko J, Elkin SL, Johnston SL, Mallia P (2019) Inflammation and infections in unreported chronic obstructive pulmonary disease exacerbations. Int J Chron Obstruct Pulmon Dis 14:823-832

11. Zhang J, Lin XF, Bai CX (2014) Comparison of clinical features between nonsmokers with COPD and smokers with COPD: a retrospective observational study. Int J Chron Obst Pulmon Dis 9:57-63

12. Donnell DEO, Parker CM (2006) COPD exacerbations - pathophysiology. Thorax. 61:4,354-4,361

13. Mullerova H, Shukla A, Hawkins A, Quint J (2014) Risk factors for acute exacerbations of COPD in a primary care population: a retrospective observational cohort study. Br Med J Open 4:12.01-12.08

14. Garcia Aymerich J, Farrero E, Felez MA, Izquierdo J, Marrades RM, Anto JM (2003) Risk factors of readmission to hospital for a COPD exacerbation: a prospective study. Thorax. 58(2):100-105

15. Hunter MH, King DE (2001) COPD: management of acute exacerbations and chronic stable disease. Am Fam Physician 64(4):603-612

16. Christopher B. Remakus, Francis Cordova, David Ciccolella, A. James Mamary, Matthew R. Lammi, Kartik V. Shenoy, Carla L. Grabianowski, John P. Gaughan, Gerard J. Criner. Outcomes of COPD exacerbations treated with corticosteroids, antibiotics, or both. Int Sch Res Notices. 2011; 01-06.

17. Sharon R Rosenburg, Ravi Kalhan. Recent advances in the management of chronic obstructive pulmonary disease. F1000 Research, 2017; 6, 863, 01-08.

18. Candela M, Costorella R, Stassaldi A, Maetrini V (2019) Giacomo curradi. Treatment of COPD: the simplicity is a resolved complexity. Multidiscip Respir Med 14(18):01-07

19. Qureshi H, Sharafkhaneh A, Hanania NA (2014) Chronic obstructive pulmonary disease exacerbations: latest evidence and clinical implications. Ther Adv Chronic Dis 5(5):212-227

20. Crisafulli E, Barbeta E, lelpo A, Torres A (2018) Management of severe acute exacerbations of COPD: an updated narrative review. Multidiscip Respir Med 13(36):01-15

21. Baker EH, Janaway $\mathrm{CH}$, Philips BJ, Brennan AL, Baines DL, Wood DM, Jones PW (2006) Hyperglycaemia is associated with poor outcomes in patients admitted to hospital with acute exacerbations of chronic obstructive pulmonary disease. Thorax. 61(4):284-289

22. Gaude GS, Rajesh BP, Chaudhury A, Hattiholi J (2015) Outcomes associated with acute exacerbations of chronic obstructive pulmonary disorder requiring hospitalization. Lung India 32(5):465-472
23. Sohy C, Pilette C, Niederman MS, Sibille Y (2002) Acute exacerbation of chronic obstructive pulmonary disease and antibiotics: what studies are still needed? Eur Respir J 19(5):966-975

24. Barnes PJ (2003) Chronic obstructive pulmonary disease 12: new treatments for COPD. Thorax 58:803-808

25. Sigurgeirsdottir J, Halidorsdottir S, Arnardottir RH, Gudmundsson G, Bjornsson EH (2019) COPD patients experiences, self-reported needs, and needs-driven strategies to cope with self management. Int J Chron Obstruct Pulmon Dis 14:1033-1043

26. Shiv Kumar G (2019) Madhuri, Anju Wilson, Tigi S George. Study of prescribing pattern of drugs in chronic obstructive pulmonary disease in tertiary care teaching hospital. I J Pharm Pract 12(3):161-166

27. Kuwal A, Joshi V, Dutt N, Singh S, Agarwal KC, Purohit G (2018) A prospective study of bacteriological etiology in hospitalized acute exacerbation of COPD patients: relationship with lung function and respiratory failure. Turk Thorac J 19(1):19-27

28. Puja B, Preethi K, Aarti S (2017) Drug use in COPD prescription patterns, and cost of medications in a multispecialty tertiary care hospital in India. World Pharm Res 6(7):1691-1697

29. Kothai R, Rangabashayan BA, Sunny PM, Nair RR, Mathew RE (2017) Analysis of prescribing pattern of COPD patients in a tertiary care hospital Salem. World J Pharm Pharm Sci 6(10):1111-1117

\section{Publisher's Note}

Springer Nature remains neutral with regard to jurisdictional claims in published maps and institutional affiliations.

\section{Submit your manuscript to a SpringerOpen ${ }^{\circ}$ journal and benefit from:}

- Convenient online submission

Rigorous peer review

- Open access: articles freely available online

High visibility within the field

- Retaining the copyright to your article

Submit your next manuscript at $\boldsymbol{\nabla}$ springeropen.com 